DOI: $10.18384 / 2310-676 X-2016-2-159-163$

ПАТРИОТИЗМ КАК НАЦИОНАЛЬНАЯ ИДЕЯ: РАЗМЫШЛЕНИЯ НАД КНИГОЙ «ПАТРИОТИЗМ И НАЦИОНАЛИЗМ КАК ФАКТОРЫ РОССИЙСКОЙ ИСТОРИИ (КОНЕЦ XVIII в.-1991 г.)» / ОТВ. РЕД. В.В. ЖУРАВЛЕВ. М.: ПОЛИТИЧЕСКАЯ ЭНЦИКЛОПЕДИЯ, 2015. 783 C.

Абрамов А.B.

Московский государственный областной университет

105005, Москва, ул. Радио, д. 10А, Российская Федерация

\title{
PATRIOTISIM AS A NATIONAL IDEA: SPECULATING ABOUT THE BOOK "PATRIOTISM AND NATIONALISM AS FACTORS OF RUSSIAN HISTORY (END OF XVIII-1991)" / EDITOR-IN-CHIEF V.V. ZHURAVLEV. M.: POLITICHESKAYA ENTSIKLOPEDIYA, 2015. 783 P.
}

\author{
A. Abramov \\ Moscow State Regional University, \\ 10 A, Radio Street, Moscow, 105005, the Russian Federation
}

3 февраля 2016 г., во время встречи с предпринимателями, входящими в Клуб лидеров, Президент России В.В. Путин неожиданно для многих объявил патриотизм национальной идеей. «У нас нет никакой и не может быть никакой другой объединяющей идеи, кроме патриотизма... Это и есть национальная идея. Она не идеологизирована, это не связано с деятельностью какой-то партии или какой-то страты в обществе. Это связано с общим объединяющим началом... И другой идеи мы не придумаем, и придумывать не надо, она есть», - заявил глава государства [1].

Слова В.В. Путина лишь на первый взгляд кажутся экспромтом. В действительности они подвели своеобразный итог начавшейся в 1990-е гг. острой политической дис- куссии о национальных интересах России. Тезис об общенациональной идее, необходимой для эффективного существования страны, стал частью российского общественно-политического дискурса еще в начале 1990-х гг., благодаря упоминанию об этом в одном из посланий Федеральному собранию РФ первого Президента России Б.Н. Ельцина. Во исполнение поручений Президента, для разработки идеи, призванной объединить всех россиян, «Российской газетой» в 1996 г. был организован конкурс. Результаты объявленного мероприятия нельзя назвать впечатляющими. Думается, что главной причиной неудачи, помимо прочего, является совершенно неудовлетворительный для того времени уровень научной рефлексии. 
Если советские авторы, писавшие на тему патриотизма, отрицали либо своеобразным образом интерпретировали дореволюционную общественную мысль, вычленяя «прогрессивных» революционных мыслителей и клеймя всех остальных как «черносотенцев и реакционеров», то в ранний постсоветский период произошло прямо противоположное. Всё советское было «сброшено с корабля истории», а произведения дореволюционных (прежде всего, либеральных) мыслителей и деятелей русской эмиграции возведены в некий непогрешимый абсолют. В этих условиях серьезный разговор о патриотизме и национальной идее оказался попросту невозможным.

Конец ельцинской эпохи и начало восстановления российской государственности, своеобразным показателем которой стало соединение российский триколора с мелодией советского гимна, сделали возможным и объективно-беспристрастное исследование проблем российского патриотизма.

В контексте вышеизложенного и следует воспринимать коллективную монографию российских историков «Патриотизм и национализм как факторы российской истории (конец XVIII в.-1991 г.)» под редакцией профессора В.В. Журавлева [3]. То, что книга вышла в свет именно в 2015 г., не является удивительным фактом, но при ближайшем рассмотрении выступает как нечто вполне закономерное.

Необходимо отметить, что авторами проделана поистине титаническая работа: в почти восьмисотстраничном томе собраны и обобщены взгляды российских писателей, публицистов и политиков конца XVIII - конца XX вв.
Книга выполнена в лучших традициях российских и советских академических изданий. Фундаментальность работе придает, разумеется, не объем, но, прежде всего, та скрупулезность, с которой составлена книга. Авторы провели широкомасштабные изыскания в дореволюционной периодике, архивах, полных собраниях сочинений разных авторов, программах политических партий; проанализировали речи советских партийно-государственных деятелей, работников культуры и искусства, буквально по крупицам извлекая, обобщая, а в ряде случаев даже реконструируя, взгляды российских политиков и общественных мыслителей.

При этом авторы столкнулись и успешно решили проблему, о которой писал профессор А.А. Ширинянц: невозможность разделить тексты на сугубо научные и художественно-публицистические и на этом основании квалифицировать имеющие место в России концепции как произведения исключительно политической мысли [4; 2]. Академичность работы ничуть не страдает от того, что авторы строят свои выводы не только на основе официальных документов и традиционных источников, но и на анализе стихов и художественных произведений соответствующего периода.

Книга состоит из введения, заключения и тринадцати глав. Введение, заключение и общая редакция выполнены руководителем авторского коллектива, профессором В.В. Журавлевым.

Главы 1-3 (авторы Н.П. Ильин, В.В. Зверев, А.Ю. Кожевников) представляют собой обзор взглядов российских мыслителей XVIII-XIX вв. на проблемы национализма и патриотизма. Впечат- 
ляет даже неполный перечень мыслителей, концепции которых освещены в данных главах: М.В. Ломоносов, Д.И. Фонвизин, Н.М. Карамзин, М.М. Сперанский, С.С. Уваров, М.П. Погодин, В.Г. Белинский, Ф.М. Достоевский, Н.Я Данилевский, А.И. Герцен, Н.Г. Чернышевский, М.А. Бакунин и др. На страницах монографии рассмотрены взгляды представителей всех течений российской общественно-политической мысли указанного периода: декабристов, западников, славянофилов, почвенников, народников. С тремя первыми главами композиционно схожа и глава 10 (автор Н.В. Антоненко), посвященная патриотизму и национализму в произведениях представителей русского зарубежья ХХ в.

Главы 4, 5 и 7, 8, принадлежащие перу П.Ю. Савельева, А.Ю. Кожевникова, А.В. Репникова Н.И. Канищевой и В.В. Шелохаева, посвящены темам патриотизма и национализма в программатике российских политических партий, движений и организаций начала XX в. Здесь авторы анализируют различные варианты (альтернативы) решения политическими силами российского национального вопроса, двигаясь по партийно-идеологическому спектру: от российских социал-демократов - к большевикам, от большевиков - к монархистам, а от них - к либералам.

Глава 6 (автор А.А. Иванов) представляет собой своеобразную "монографию в монографии» и посвящена анализу истории появления лозунга «Россия для русских».

Завершающие главы монографии, написанные А.Ю. Кожевникым (главы 9-12) и Л.Н. Доброхотым (глава 13), построены по хронологическому принципу и описывают трансформацию представлений о патриотизме и национализме в советском государстве (во властных верхах и интеллигенции) с 1917 до 1991 гг.

Всю работу объединяет характерное для историков уважение к факту, а в данном случае - к слову. В отличие от значительной части современных работ, посвященных патриотизму, где серьезный анализ проблемы зачастую подменяется общими и подчас спекулятивными рассуждениями авторов, данная монография предельно конкретна. Все умозаключения авторов подкреплены обширными цитатами и отсылочными сносками. Всё это позволяет без преувеличения квалифицировать работу как своеобразную энциклопедию российской патриотической мысли.

Но, наряду с несомненными достоинствами работы, следует указать на имеющиеся исследовательские резервы. Во-первых, как политологу автору данных строк решительно недостает в рецензируемой коллективной монографии теоретической главы, в которой бы ясно формулировались основные дефиниции исследовательского проекта: национализм, патриотизм, шовинизм, ксенофобия, космополитизм и т.п. В случае с рецензируемой монографией повествование начинается «с места в карьер»: автору первой главы приходится определять данные понятия применительно к конкретноисторическому материалу: общественной мысли и публицистике XVIII в.

Во-вторых, дискуссионным представляется тезис о точке отсчета российского патриотизма и национализма. Неясно, почему авторы проигнорировали обширный этап начала русской государственности, начав повествование лишь 
c XVIII в. Утверждение о том, что до Петра I в русском языке отсутствовало слово «нация» и потому именно Петровскую эпоху нужно назвать «временем рождения русского национализма» $[3$, с. 9], является явной натяжкой. Вероятнее всего, причина выбора XVIII в. как начала отсчета связана с тем, что сам период с начала российской государственности до эпохи Петра Великого настолько масштабен и полон именами, произведениями и событиями, что достоин отдельного проекта. Будем надеяться, что в будущем нас ждет именно такой «приквел» к существующей книге.

Указанные замечания носят, безусловно, дискуссионный характер и не снижают высокой ценности издания. Несомненным является лишь то, что выход рецензируемой книги, не име- ющей аналогов в современной общественной науке, является важнейшим событием в российской исторической, политической, философской и социологической мысли постсоветского периода.

И последнее. Накануне сдачи рецензии в журнал пришло радостное известие: книга «Патриотизм и национализм как факторы российской истории» стала лауреатом конкурса «Национальная премия «Лучшие книги и издательства года - 2015» в номинации «Философия», разделив эту награду с книгой Патриарха Московского и всея Руси Кирилла и циклом философскоаналитических статей в «Литературной газете» А. Щипкова [5]. От всей души хочется поздравить авторов с этой заслуженной наградой.

\section{ЛИТЕРАТУРА}

1. В.В. Путин. Встреча с активом Клуба лидеров // Президент России [официальный сайт]. URL: http://www.kremlin.ru/events/president/news/51263 (дата обращения: 25.03.2016)

2. Горохов А.А., Зеленин Ю.А. Теоретико-методологические проблемы истории русской социально-политической мысли // Вестник Московского государственного областного университета (Электронный журнал). 2015. № 1.

3. Патриотизм и национализм как факторы российской истории (конец XVIII-1991г.) / отв. ред. В.В. Журавлев. М.: Политическая энциклопедия, 2015. 783 с.

4. Ширинянц А.А. О специфике истории социально-политической мысли России // Общественная мысль России: истоки, эволюция, основные направления. Материалы международной научной конференции. Москва, 28-29 октября 2010 г. М.: Российская политическая энциклопедия, 2011. С. 536-546.

5. Национальная премия «Лучшие книги и издательства года - 2015» // Литературная газета. 2016. 3 марта.

\section{REFERENCES}

1. Putin. Vstrecha s aktivom Kluba liderov [Putin. Meeting with Activists from Leaders Club] Prezident Rossii [ofitsial'nyi sait]. [The President of Russia [official website].]. - URL: http:// www.kremlin.ru/events/president/news/51263 (request date 25.03.2016)

2. Gorokhov A.A., Zelenin YU.A. Teoretiko-metodologicheskie problemy istorii russkoi sotsial'no-politicheskoi mysli [Theoretical-Methodological Problems of the Russian SocioPolitical Thought History] // Vestnik Moskovskogo gosudarstvennogo oblastnogo universiteta (Elektronnyi zhurnal). 2015. no. 1. pp. 1-8.

3. Patriotizm i natsionalizm kak faktory rossiiskoi istorii (konets XVIII-1991 g.) [Patriotism and Nationalism as Factors of Russian History (the end of XVIII-1991) / resp. edited by V. V. Zhuravlev]. M., Politicheskaya entsiklopediya, 2015. 783 p. 
4. Shirinyants A.A. O spetsifike istorii sotsial'no-politicheskoi mysli Rossii [About the Specifics of Social and Political Thought in Russia] Obshchestvennaya mysl' Rossii: istoki, evolyutsiya, osnovnye napravleniya. Materialy mezhdunarodnoi nauchnoi konferentsii. Moskva, 28-29 oktyabrya 2010 g [Public Opinion in Russia: Origins, Evolution, Main Directions. Proceedings of the International Scientific Conference. Moscow, October 28-29, 2010]. M., Rossiiskaya politicheskaya entsiklopediya, 2011. pp. 536-546

5. Natsional'naya premiya «Luchshie knigi i izdatel'stva goda (National Prize "Best Books and Publishers of the Year) // Literaturnaya gazeta, 2016, March 3.

\section{ИНФОРМАЦИЯ ОБ АВТОРЕ}

Абрамов Андрей Вячеславович - кандидат политических наук, доцент, доцент кафедры политологии и права Московского государственного областного университета; e-mail: abram-off@mail.ru

\section{INFORMATION ABOUT THE AUTHOR}

Abramov Andrey V. - Political Science, Associate Professor, Associate Professor of the Department ofPolitical Science and Law, Moscow State Regional University; e-mail: abram-off@mail.ru

\section{БИБЛИОГРАФИЧЕСКАЯ ССЫЛКА}

Абрамов А.В. Патриотизм как национальная идея: размышления над книгой «Патриотизм и национализм как факторы российской истории (конец XVIII-1991г.)» / отв. ред. В.В. Журавлев. М.: Политическая энциклопедия, 2015. 783 с. // Вестник Московского государственного областного университета. Серия: История и политические науки. 2016. № 2. С. 159-163.

DOI: $10.18384 / 2310-676 \mathrm{X}-2016-2-159-163$

\section{BIBLIOGRAPHIC REFERENCE}

A. Abramov. Patriotism as a national idea: speculating about the book "Patriotism and Nationalism as Factors of Russian History (end of XVIII-1991)" / editor-in-chief V.V. Zhuravlev. M.: Politicheskaya Entsiklopediya, 2015. 783 p. // Bulletin of Moscow State Regional University. Series: History and Politic Sciences. 2016. no 2. pp. 159-163.

DOI: $10.18384 / 2310-676 \mathrm{X}-2016-2-159-163$ 